\title{
Fictionalized Accounts of African Migrant Mothers in And Breathe Normally and Anchor Baby
}

And Breathe Normally ve Anchor Baby adlı Filmlerde Afrikalı Göçmen Annelerin Kurgusal Hayatları

\author{
Omotoyosi E. Odukomaiya \\ Southern Illinois University, Carbondale, USA
}

\begin{abstract}
Representations and discourses about migrants have excluded the narratives of African migrant mothers. Often, discussions about these group of women tend to rely on stereotypes, which consequently trivializes the complexities and nuances that characterize the lives of these women. Adopting an intersectional approach, this article centers the African immigrant mother by exploring the narratives of African migrant mothers in two films. In this article, I explore how institutional systems combine to oppress African migrant mothers in their host nations. While And Breathe Normally (2018) challenges the notion of female passivity-which shapes numerous mainstream Hollywood films-Anchor Baby (2010) perpetuates some patriarchal norms associated with motherhood. However, both films demonstrate the multiple layers of oppression that African migrant mothers encounter in the host country. Through the individual narratives of all the female characters (black and white) in both films, we can see each one of them has personal battles imposed on them by their societies, thereby highlighting how interconnected the lives of women are.

Keywords: African migrant mothers, Hollywood stereotypes, And Breathe Normally, Anchor Baby, Intersectional feminism

Öz

Göçmenler üzerine olan yansıtmalar ve oluşturulan söylemler Afrikalı göçmen annelerin anlatılarını dışarıda tutar. Bu kadınlar üzerine olan tartışmalar, onların hayat hikayelerini özelleştiren ayrıntıları önemsiz kılan stereotipler üzerine kuruludur. Bu çalışma, Afrikalı göçmen annelerin anlatılarını iki film üzerinden irdeleyerek onları merkeze alır. Ayrıca, Afrikalı göçmen annelerin yerleştikleri ülkelerde endüstri tarafından sistemsel olarak nasıl baskılandıklarını araştırmayı amaçlar. And Breathe Normally, Hollywood filmlerinde sıklıkla karşılaşılan pasif kadın algısına karşı çıkar. Öte yandan, Anchor Baby ise annelikle ilişkilendirilen erkekegemen normları pekiştirmektedir. Ancak her iki filmde de Afrikalı göçmen annelerin maruz kaldığı baskıcı yapı farklı boyutlarıyla sergilenir. Kadın karakterlerin bireysel hikayeleri üzerinden her birinin kişisel mücadeleleri bu iki filmde de aktarılır.

Anahtar Kelimeler: Afrikalı göçmen anneler, Hollywood stereotipleri, And Breathe Normally, Anchor Baby, keşisimsel feminizm
\end{abstract}

\section{Introduction}

Contemporary feminist film critics such as Anneke Smelik and Jane Gaines have argued that a film theory based on a psychoanalytic framework is not sufficient

CUJHSS, June 2021; 15/1: 151-162.

(C) Çankaya University ISSN 1309-6761 Printed in Ankara

Submitted: Feb 22, 2021; Accepted: June 4, 2021

ORCID\#: 0000-0001-6850-6997; esther.oduko@siu.edu 
because it fails to take other differences, such as race, class, age and sexual preference, into account. These critics contend that leading feminist film theorists like Laura Mulvey, are just as culpable as the Hollywood producers who project women as passive sexual objects in their films. Mulvey's male gaze theory, which is founded on Freud's concept i.e., scopophilia, shows that mainstream cinema typically provides pleasure for male spectators. According to Mulvey, the pleasure offered by mainstream cinema is merely a reinforcement of "pre-existing patterns of fascination already at work" (57) in societies, in such a way that "pleasure in looking" in cinema "has been split between active/male and passive/female" (62). Cynthia Freeland, Professor of Philosophy at the University of Houston, Texas, alleges that Mulvey gives little possibilities for critical engagement. Freeland argues that Mulvey does not raise issues that demonstrate the differences existing among women. Given the nature of the films chosen for this essay, Mulvey's theory on visual pleasure may be inadequate to fully analyze the films. Since the protagonists of both films are African migrant women, Kimberle Crenshaw's intersectional theory which centers minority women, will be beneficial in the discussion of the films. A rhetorical analysis of the films will also be valuable, especially as Flo Leibowitz, a feminist film critic, observes its effectiveness. Leibowitz in her essay entitled "Apt Feelings or Why Women's Films Aren't Trivial" argues, in her analysis of several melodramatic films that "films evoke emotions by means of their narratives" (225). The film critic contends that these emotions, as depicted through a film's narrative, enables the audiences identify with characters-which Leibowitz refers to a "cognitive model of film" (226). While the intersectional theory will highlight the lived experiences of the women-as portrayed in both films, a rhetorical analysis of spoken and unspoken narratives is equally significant in order to fully understand the complexities of the lives of these women.

In light of this, I turn to the intersectional theory which illustrates how gender, race and sex intersect with other aspects of a woman's identity that combine in a unique way to oppress women (most especially women of color and black women). African migrant women, are faced with a harsh reality, resulting from power dynamics (ranging from racial, economical to patriarchal). One striking similarity across many films and literary works that address issues affecting migrants, is that they tend to depict ways in which an immigrant's fear could also be fears that citizens may be familiar with. In other words, the fear of the unknown, which can play out in many ways, becomes a general theme that both the undocumented migrant and the citizen can relate to, thus making the immigrant's fear a familiar one. This paper aims to explore the representations of migrant mothers, more specifically African migrant mothers in two films. The two primary films that will be at the center of the discussion in this article are Anchor Baby (2010) and And Breathe Normally (2018).

\section{Intersectional Feminism}

Kimberle Crenshaw, who coined the term "Intersectionality" contextualizes the definition of the concept, as the theorist asserts that because of identity 
politics, it has become apparent for many women to see how their identities intersect or interlock and that "the experiences of women of color are frequently the product of intersecting patterns of racism and sexism" (1243). Crenshaw further argues that "because of their intersectional identity as both women and of color within discourses that are shaped to respond to one or the other, women of color are marginalized within both" (1244).

Intersectional feminist critics, Kathy Davis and Michelle Flood agree that intersectionality is increasingly gaining traction, as more women continually identify with the term. In her article titled "Intersectionality as Buzzword," Kathy Davis affirms that intersectional feminism has become so prevalent that it has been reduced to a "buzzword" (75). Similarly, Michelle Flood in the publication titled "Intersectionality and Celebrity Culture" notes that several celebrities have endorsed intersectional feminism, consequently making the term a "mainstay term in celebrity discourse" (422). Flood concludes that intersectionality has lost its real theoretical value because of how celebrities use the term as "a self-congratulatory sticker on a laptop" (423). Robby Soave, an editor at Reason, argues that the consequence for the adulteration of the ideology is that it decentralizes the issues of minority women, who are often overlaid with inequalities in multiple intersecting domains (race, class, place of residence etc.). Essentially, while it is true that intersectionality embraces the need to understand individual lives in order to identify intersecting and overlapping identities, this can sometimes be difficult. Hence, Soave cautions that the focus of this ideology must be centered majorly on those whom the theory was created for-Black, poor women. The films discussed in this paper take Soave's argument into consideration, because the protagonist of both films are Black women.

While white middle class women face oppression from patriarchy, numerous African American women must battle with social class inequality, sexism, and racism. bell hooks, an African American feminist critic writes: "white women who dominate feminist discourse, who for the most part make and articulate feminist theory, have little or no understanding of white supremacy as a racial politics, of the psychological impact of class, of their political status within a racist, sexist, capitalist state" (35). In other words, intersectional feminists are critical of mainstream feminists, a largely white middle class group, for excluding black women, as well as women of color who have diverse intersecting identities. Immigration, as a power structure, oppresses the migrant woman, perhaps in the same way patriarchy and racism do, but migrant women, who make up over half of the population of all immigrants are oppressed by the three systems (racism, patriarchy, and immigration). Annie Phizacklea, notes that women "constitute half of the world's migrants and $80 \%$ of the world's population" (321). Relatedly, the United Nations Populations Fund report that not only do these migrant women suffer sexual exploitation, trafficking, and violence, but they also encounter multiple discrimination as women and as migrants mainly because of the negative depictions of 
immigrants in the media. ${ }^{1}$ Apparently, the African migrant mothers must deal with a triple dose of oppression than their white, middle-class counterparts.

Although the African American woman and the African migrant are of the same race, what sets them apart goes beyond the immigration status of both women. Soave states that the multiple experiences that can co-occur for an African woman, and in this instance, an African migrant mother is what he refers to as a "unique experience" of oppression. Accordingly, an African migrant woman's experience is a cumulative one that transcends that of an immigrant, because such a woman has distinctive experiences that she brings with from her home country to the host country. As such, these experiences (past and present) may create some sort of disorientation for the African migrant mother. For Soave, "experience" is significant in understanding intersectionality as an ideology. Heather Hewett, author of "Mothering Across Borders: Narratives of Immigrant Mothers in the United States," argues that while most authors have acknowledged "the full complexity of mother's lives and experiences" few have addressed the difficulties migrant mothers face (121). As such, Hewett's argument further establishes the claims of intersectional feminists, which makes a case for the inclusion of all women in the activism promoted by mainstream feminists. Ana- Maria Deliu and Laura Ilea, reecho Hewett's assertion as they affirm that "intersectionality decenters the universal woman" and consequently maintain that "there are more particular groups of women within the dominant model" (11). Fundamentally, while mainstream feminists exclude the narratives of the African American woman, it also ignores the African migrant from the feminist agenda. Intersectional feminists attempt to include all women with different identities in the fight against patriarchy. As a result, it is significant that the voices of African migrant mothers are heard, and their stories are told.

\section{Isold Uggadottir, And Breathe Normally}

And Breathe Normally (2018), written and directed by Isold Uggadottir addresses many of the concerns of intersectional feminists. The film foregrounds issues that border on race, immigration, and identity, most especially for women with children. Uggadottir's film gives an account of Lara, an underprivileged Icelandic mother, who meets a Guinea-Bissauan mother named Adja in an airport in Iceland. The accidental meeting of these women depicts how inevitably linked they are, even though they appear to be seemingly different. The film begins with Lara, a Caucasian woman, financially incapable of paying for her groceries, but rejects help from a stranger wanting to assist her. Lara's anxieties become apparent as she intentionally ignores her mailbox, only to be reminded by her son. Eldar, the awe-inspiring child, unlocks his mother's mailbox and hands Lara a deluge of mails, a reminder of the financial burden she bears.

\footnotetext{
1 United Nations Population Fund. "Five Reasons Migration Is a Feminist Issue." 9 Apr 2018. unfpa.org/news/five-reasons-migration-feminist-issue. Accessed 10 Dec. 2020.
} 
Adja, Uggadottir's second protagonist, a Guinea Bissauan refugee, on her way to Canada from France meets Lara, an immigration officer training on the job with a superior immigration officer. As Lara's boss stamps Adja's passport, Lara, notifies her boss of what she suspects to be a fake passport. Adja's challenges begin to unfold at this point as they detain her at a facility for further questioning. However, Adja's daughter, accompanied by Adja's sister, gets past border security. Evidently, the lives of Adja and Lara reveal that although both women have seemingly different lives, they share very similar difficulties. Isold Uggadottir, humanizes the African migrant, by depicting her woes as a familiar one to the European, consequently demystifying the challenges migrants' battle. Lara empathizes with Adja because she can envision how her greatest fears, may get the best of her, and perhaps result in uncertain outcomes like the immigrant's. Lara's impoverished life unfolds throughout the greater part of the film. She receives frequent phone calls from her landlord, reminding her of unpaid rent. With no roof over their heads, Lara abandons her home and says to her son, "we are going on a secret adventure where people like us go" (And Breath Normally), leaving her with no option but to make her car, a home. Through these scenes, viewers can make connections between the battles of immigrants and that of citizens. These representations make it apparent for viewers to see how Uggadottir effectively moves away from the male gaze to focus on female spectatorship, since viewers can see themselves in either one of the protagonists and empathize with the characters. According to feminist film theorist, Laura Mulvey, these depictions counter the portrayals of female characters in mainstream cinema. Mulvey in her groundbreaking essay entitled Visual Pleasure and Narrative Cinema argues that films tend to perpetuate the patriarchal society such that "socially established interpretations of sexual difference" controls how female characters are framed in films (57). Contrasting these mainstream films that objectify and eroticize women, the protagonists, Lara and Adja challenge these stereotypical representations of women in mainstream cinema.

Unlike most Hollywood films, And Breathe Normally, can be described as a counter-cinema or what Mulvey calls "alternative cinema" (61) that challenges the notion of female passivity, because the protagonists are female. Female passivity hinges on Mulvey's theory that women in mainstream American films exist only to please the male protagonist, consequently they do not act on their own accord but serve as appendages to the male protagonist. The case is quite different in And Breath Normally. On very rare occasions do we see any male characters through-out the entire duration of the film. More importantly, Isold Uggadottir gives room for female subjectivity where women depend on other women and not men for support. Lara sees herself in Adja's position as a deprived mother battling oppressive forces that we may consider to be two sides of the same coin (i.e., racism, capitalism, sexism). Subsequently, it is obvious to see how the film adopts an intersectional approach to tell the story. As an immigrant, Adja faces double the oppression Lara encounters. The oppressive forces Adja grapples with outside of her home country are multilayered. Adja's identity as a woman, a mother, an immigrant and an 
African intersect to marginalize her in a unique way that only she can express. Adja, who rarely speaks throughout the entire film, seemingly appears to be a complex character, and this challenges the notions of mainstream cinema that the lives of women are simple (or that women are a monolithic group). From her first appearance we can tell that Adja is holding back onto some unspoken difficulties. One critic describes Adja as "a less well-defined, more mysterious figure... who has learnt the wisdom of keeping her true feelings under wraps" (Hunter). Even before her encounter with border control, Adja's physical and facial expression demonstrates that she is overwhelmed by deep insecurities. Although no information is given about where she arrives from, we can conclude that she was either migrating from Guinea or France (where she was also an immigrant). As the film progresses, we get to understand that not only is Adja a mother, as her daughter and sister successfully get past border security with fake passports on a flight to Canada, but that Icelandic immigration officials separates Adja from her daughter.

Most migrants experience liminality as they struggle to integrate socially, economically, and mentally in the host countries. As is the case with most immigrants, Adja appears to occupy double liminal spaces as a migrant and a mother. According to Courtney Wittekind, who undertakes an anthropological study on the liminality and landscape across the Thailand-Burma Border, contends that the "liminal is neither here nor there but is betwixt and bet/ween, existing outside of standard social expectations that order behavior" (182). Another author agrees that liminality is a period of transition between the "old way of being and the new" and that during a liminal period a person is a person is "stripped of their social status and they experience a sense of ambiguity and disorientation" (Archos). Archos reiterates that an immigrant mother is more likely to experience a multiplex form of disorientation, especially regarding raising a child. Archos's description undoubtedly describes Adja's position as a migrant mother. As a migrant, Adja is trapped physically -in Iceland-and mentally since she is on the verge of realizing her dream of successfully migrating to Canada. Adja is stripped of her sense of self as they detain her and put her with other migrants, like criminals. In her attempt to gain a sense of control of her life, Adja asks the detention officer, "do you know how long I have to stay here" (And Breath Normally) to which the officer responds, "No, I do not know, it is just the system. Good luck to you" (And Breath Normally). Adja witnesses the Icelandic Immigration officials jostle and force another immigrant into a car at midnight, and she wonders if that will also be her fate and asks her "detention mate," why they deport immigrants in the middle of the night. This scene frightens Adja and possibly disorientates her psychologically as she considers escaping from the detention facility. As a mother, Adja also experiences liminality, as she wonders if she would ever get to see her child again.

Iceland exists as a liminal space for Adja, in the sense that she is in the transition to her destination, which is Canada. Space, according to Arvanitis et al, is constructed through its "physical, mental, and social dimensions" (136). In other words, Adja's liminality exists on three levels, mentally, physically (as 
stated earlier) and socially, and they all work together to destabilize Adja. Her lived experiences in the detention facility as well as her social interactions with other immigrants, intensify Adja's "in-betweenness" as she becomes conscious of the necessary steps she must take to escape from detention. Eleanor Paynter, who recognizes immigrants like Adja, as transit migrants, says that transit migration "does not correspond to a set of laws or rights ... it is not a recognizable legal category" (41). In other words, Adja, lives "in an ongoing state of non-arrival" since the Icelandic immigration authorities keep her in detention indefinitely because of her status as a transit migrant (Paynter 41). For a transit migrant like Adja, the detention facility creates contrary emotions, as she has to grapple with both ambiguities of her situation and the new possibilities of integrating into the host country (i.e., Canada). During one of her visits to her immigration lawyer, Adja asks the lawyer if there are any other options for her to leave Iceland. Adja's desperation to leave Iceland becomes visible as she assumes that she will be allowed to leave Iceland to file for asylum in Canada. Unfortunately, the lawyer says to her, "without a valid Guinea Bissauan passport, this is not a viable option" (And Breath Normally). Not only does Iceland represent a stumbling block for Adja, but it also prevents a unification with her daughter in Canada.

Additionally, Uggadottir, successfully integrates subtle motifs critical of the immigration policies of the Trump administration in the United States. Lara takes her son to a home for abandoned cats. Eldar, who is confused to see cats living in cages, asks his mum, out of curiosity, why there are numerous caged cats, to which she responds, "there is no one to look after them" (And Breath Normally). Eldar, in a state of utter bewilderment, asks Lara why the cats cannot look after themselves, but she responds, "because someone decides so" (And Breath Normally). This scene concludes with Eldar stating that "it is strange to live in a cage" and then he picks one of the cats to adopt (And Breath Normally). Symbolically, through this scene, we can infer that Uggadottir, not only humanizes immigrants as individuals who have rights to freedom but also as people who are deserving of a warm welcome.

\section{Lonzo Nzekwe, Anchor Baby}

Anchor Baby (2010), written and directed by Lonso Nzekwe, tells the story of a Nigerian couple, Joyce, and Paul Unanga, whom in the hopes of securing a better life for their unborn child, decide to remain in America illegally, four months after their visas had expired. The Unangas planned to return to Nigeria, once they have their baby on American soil because they believe that their child will have limitless opportunities as a US citizen. Arising from this desperate desire to have their unborn child become a citizen of America, they ignore ICE's notification for voluntary removal. Unfortunately, ICE immigration officials raid the restaurant where Paul works. ICE arrest and eventually deports Paul to Nigeria, leaving Joyce to survive by herself on a foreign land.

Unlike Adja, whose child is separated from her, Joyce carries her child inside of her, thus making Joyce's motherhood situation intricate. Sarah Garcia, author or "Maternal Communication Concerning Immigration Status," identifies 
discussions of immigration status as "a stressor to immigrant families" (284). Garcia, whose research objective centers on the implications of parental immigrant status on early childhood education to adolescence, affirms that a "mothers' undocumented immigration status negatively impacted their U.S. citizen children's early development" and that these children have a higher anxiety level (285-286). Anchor Baby sheds light on the implications of motherhood and its intersection with displacement and migration. Joyce, who is a mother-to-be, strongly believes that an American passport for her child is all she needs to have to provide a good life for her child. While Joyce's husband wishes for a bright future for their unborn child, he has a more positive disposition, even after his deportation. Joyce, on the other hand, has nightmares because of the concerns she has about her undocumented status. Joyce appears constantly burdened and worried that she may be unable to fulfill their desires for their child as she says, "we have four more months before the baby comes and we are hiding from ICE" (Anchor Baby). Although Joyce desperately wants the US citizenship for her child, she contemplates returning to Nigeria without fulfilling her aspirations, but her husband jolts her back to reality, reminding her of the endless opportunities they run the risk of losing.

Paul's absence exacerbates the struggles that Joyce faces as a mother in a foreign country, but his absence certainly gives Joyce agency. We can see a parallel in And Breathe Normally, as there is a conspicuous absence of a male/father figure for Adja's daughter. Like Adja, Joyce struggles to deal with the harsh realities of navigating her host country without immigration papers. Joyce is unable to rent an apartment and settles for a motel temporarily since she has no source of identification. Bureaucracies seemingly make the lives of both women more difficult as immigrants living in a foreign country. Crenshaw, who understudies women of color immigrants in a women's shelter, reiterates a similar thought: "intersectional subordination need not be intentionally produced; in fact, it is frequently the consequence of the imposition of one burden that interacts with preexisting vulnerabilities to create yet another dimension of disempowerment" (1249). In other words, the various aspects of a woman's identity serve "as preexisting vulnerabilities" which intersect with institutional structures thus rendering such a woman helpless (1249). In the cases of Adja and Joyce, their identities as mothers "interact with their preexisting vulnerabilities" as undocumented immigrants (1249). On the one hand, Joyce, who appears to be heavily pregnant, can neither get a rented home nor see a doctor for prenatal visits because she has no insurance or identification card. On the other, immigration officers at the facility where they detain her, deny Adja access to some accessories belonging to her daughter, which may ease the pain she feels from being away from her daughter. There are a couple of other instances where the officials repeatedly say to Adja, "these are just the rules," thus suggesting that the rules, which appear to be discretionary, can never be broken under any circumstances.

In both cases, Adja and Joyce experience difficulties because of the immigration policies and bureaucracies. The bureaucracies prevent both mothers from 
being close to their children, even in the least manner possible. For Joyce, she, unlike any other mother, cannot experience the joy of examining her baby's health or even determine the gender of her child, through an ultrasound scan. Also, Icelandic officials prevent Adja from holding onto items which remind her of her child. As such, it becomes apparent that not only do these women have to deal with the complexities associated with motherhood, they do so with other anxieties related to their immigration status and their economic status, since they are both unable to work legally, neither do they have men providing for them.

Hewett notes that many discussions about the complexities of motherhood challenge "cultural narratives about what it means to be a good mother" (121), thus implying that from a traditional motherhood perspective, migrant mothers like Joyce may be stereotyped as bad mothers because of the choices they make. In the same vein, Joanna Dreby, who conducts a study on the emotional consequences of transnational motherhood and fatherhood, contends that Mexican mothers-the focus of her study-as well as transnational mothers tend to demonstrate "emotional intimacy from a distance" (34). The idealized notion of what a good mother should be, is also central to Lonzo Nzekwe's Anchor Baby, perhaps in a more nuanced manner. While it is apparent that Joyce is willing to go to great lengths to secure a better life for her unborn child, she puts the life of her child at great risk for going several months without prenatal care. The question that arises then is, at what point does a mother draw the lines between doing what is best for the future and what is good for the child, momentarily? Lynda Ross's Interrogating Motherhood provides answers to this question. Ross, in her text addresses the struggles of mothers who do not fit into the western ideology of motherhood. The critic argues that these kinds of mothers can be categorized as "other mothers" and that they vary typically, ranging from mothers who "combine work with mothering, mothers who mother in poverty, disabled mothers...single mothers, lesbian mothers, and fathers" (103). Ross contemplates that although the universal concept of motherhood, which is emblematic of the "wonders and joys of motherhood," is celebrated in the contemporary western world" (2), but the reality is that not all women can have the same experiences or disposition about motherhood. The lived lives of many women are marked by complex realities (social, political, economic, cultural), which may have consequences on the child's wellbeing. In other words, although Joyce's decision to remain in the US illegally, separates her from her unborn child metaphorically, the mothering decisions of Joyce as well as Adja, from Ross's perspectives, precludes them from the "bad mother" stereotype. Though her decision to remain in the US illegally has dire consequences on the child's wellbeing, as she puts the child at risk, Ross argues that the decisions that mothers like Joyce makes, principally results from the social, economic, political situations in their home countries, so in the grand scheme of things, they are not bad mothers. Both mothers are "good" because they love their children and make decisions that they deem necessary for the comfort and benefit of their children. 
The absence of men in the lives of the major protagonists indicate that the women have agency and as a result, are empowered. Sutherland and Feltey, in their article titled "Here's Looking at Her: An Intersectional Analysis of Women, Power and Feminism in Film" which discusses distinctive features of feminist films, provide a framework that highlights how women are empowered in film. The "powers" highlighted include: 1. power-over, defined as power gained by a female actor, where she carries out her will over another through domination and exploitation, 2. power-to, described as a woman's struggle to defy "social norms as they attempt to establish independent, autonomous identity outside of societal institutions" (Sutherland and Feltey 8) 3. power-with, characterized as an alliance built among women to "enact social change" (Sutherland and Feltey 10). There is a manifestation of power-with in both films since we see women who build coalition against oppressive forces. In the absence of father figures, other women rise to support Joyce and Adja. Joyce, who attempts to get health care at a doctor's office, meets an African American named Susan. Susan offers Joyce accommodation for the duration of her pregnancy and she seemingly appears to be unbelievably kind, until we later find out that she has dubious intentions. The interests of both women intersect on the topic of motherhood, as Joyce is heavily pregnant while Susan battles with infertility. Susan's infertility and desperation for a child bears its foundation in pronatalism, a belief that promotes the idea that women must procreate. Pronatalism is another oppressive force that many African women battle with, but this subject is outside the purview of this article. Similarly, Adja receives overwhelming support from Lara, who eventually assists Adja in getting past the border control officers at the airport. Lara, a single mother, also receives sympathy from an unnamed woman who is sexually interested in Lara. Each one of these women understand how oppressive the institutional systems are, so they collaborate to challenge the oppressive systems. Susan in her desperate desires to become a mother, demonstrates the power-over since she uses her privilege as a US Citizen to exploit a helpless immigrant mother, and kidnaps Joyce's newborn. It is important to state that, it appears that the director, who is male, punishes Joyce for supposedly being a "bad mother". It is precisely for this reason that feminist film critics advocate for more female directors who can direct feminist films.

\section{Conclusion}

And Breathe Normally and Anchor Baby depict the underrepresented narratives of migrant mothers in the American popular culture. These women, who are African, mothers and immigrants experience multiple forms of oppression resulting from the intersection of these identities. Even though both films foreground the struggles of African migrant mothers, they also project how capitalist, patriarchal societies oppress all women, regardless of immigration status or race. It is for this reason that Rebecca Clark notes that black feminism is all-encompassing as it is inclusive of all identities. In other words, the black race represents the dividing line that cuts across all oppressive power structures. Although characters in both films are not conspicuously racially oppressed, the protagonists of both films are Africans thus implying the racist 
tendencies of immigration enforcement bodies. Other underlying issues explored, beyond immigration, include infertility, as previously mentioned, lesbianism and cyclical poverty. Through the individual narratives of all the female characters in both films, we can see each one of them have personal battles imposed on them by their societies thus highlighting how interconnected the lives of women are. While these films-to a great extenteffectively demonstrate the lived experiences of African migrant mothers, who have been excluded from the mainstream media cinema, it is important that more women of color and African women are given the opportunities to produce and direct these films, because they bring their experiences as women of color in the way the stories are told and more importantly, they become empowered by such roles.

\section{Works Cited}

Archos, Irene. "Liminality of Immigration: Losing Cultural Identity Through Motherhood." Greek American Girl, 8 March 2020, greekamericangirl.com /living-liminality-immigrant-motherhood/. Accessed 7 Dec. 2020.

Arvanitis, Eugenia, et al. "Liminal Spaces of Temporary Dwellings: Transitioning to New Lives in Times of Crisis." Journal of Research in Childhood Education, vol. 33, no. 1, Jan. 2019, pp. 134-144.

Berger, Michele Tracy, and Kathleen Guidroz. The Intersectional Approach: Transforming the Academy through Race, Class, and Gender. University of North Carolina Press, 2009.

Boland, Tom, and Ray Griffin. "The Death of Unemployment and the Birth of JobSeeking in Welfare Policy: Governing a Liminal Experience." Irish Journal of Sociology, vol. 23, no. 2, Nov. 2015, pp. 29-48.

Clark, Rebecca. "Eloquent Rage: Black and Intersectional Feminism for 'Grown-Ass Women."' Resources for Gender \& Women's Studies: A Feminist Review, vol. 39, no. 3/4, Summer/Fall2018 2018, pp. 7-9.

Crenshaw, Kimberle. "Mapping the Margins: Intersectionality, Identity Politics, and Violence against Women of Color." Stanford Law Review, vol. 43. No 6 Jul. 1991, pp. 1241-1299.

Davis, Kathy. "Intersectionality as Buzzword: A Sociology of Science Perspective on What Makes a Feminist Theory Successful." Feminist Theory, vol. 9, no. 1, April 2008, pp. 67-85.

Deliu, Ana-Maria, and Laura T. Ilea. "Combined and Uneven Feminism: Intersectional and Post-Constructivist Tendencies." Metacritic Journal for Comparative Studies \& Theory, vol. 4, no. 1, July 2018, pp. 5-21.

Dreby, Joanna. "Honor and Virtue: Mexican Parenting in the Transnational Context." Gender \& Society, vol. 20, no. 1, Feb. 2006, pp. 32-59.

Flood, Michelle. "Intersectionality and Celebrity Culture." Women's Studies in Communication, vol. 42, no. 4, Nov. 2019, pp. 422-426.

Freeland, Cynthia. "Feminist Film Theory." Draft for the Encyclopedia of Aesthetics forthcoming from Oxford University Press, edited by Michael Kelly, uh.edu/ cfreelan/courses/femfilm.html. Accessed 4, Dec. 2020 
Hewett, Heather. "Mothering across Borders: Narratives of Immigrant Mothers in the United States." Women's Studies Quarterly, vol. 37, no. 3/4, Fall/Winter2009 2009, p. 121-139.

Hopkins, Peter. "Social Geography I: Intersectionality." Progress in Human Geography, vol. 43, no. 5, Oct. 2019, pp. 937-947.

Hunter, Allen. "And Breathe Normally: Sundance Review." Screen Daily, 19 Jan 2018 screendaily.com/reviews/and-breathe-normally-sundance-review/5125531. Accessed 7 Dec. 2020.

Kirk, Kate, Ellen Bal, and Sarah Renee Janssen. "Migrants in Liminal Time and Space: An Exploration of the Experiences of Highly Skilled Indian Bachelors in Amsterdam." Journal of Ethnic and Migration Studies, vol. 43, no.16, Dec. 2017, pp. 2771-2787.

Leibowitz, Flo. “Apt Feelings or Why Women's Films' Aren't Trivial.” Post-Theory: Reconstructing Film Studies, edited by David Bordwell and Noel Carroll, Madison: University of Wisconsin Press, 1996, pp. 219-229.

Mulvey, Laura. "Visual Pleasure and Narrative Cinema." Screen 16.3 (1975): 6-18.

Nzekwe, Lonzo, director. Anchor Baby. Tubi TV, 2010.

Paynter, Eleanor. "The Liminal Lives of Europe's Transit Migrants." Contexts: Understanding People in Their Social Worlds, vol. 17, no. 2, Spring 2018, pp. 40-5.

Phizacklea , Annie. "Women, Migration and the State." Feminism and 'Race,' edited by Bhavnani, Kum-Kum Oxford; New York: Oxford University Press, 2001, pp 319330.

Rendón García, Sarah A. “No Vamos a Tapar El Sol Con Un Dedo': Maternal Communication Concerning Immigration Status." Journal of Latinx Psychology, vol. 7, no. 4, Nov. 2019, pp. 284-303.

Ross, Lynda Rachelle. Interrogating Motherhood. AU Press, 2016.

Sutherland, Jean-Anne, and Kathryn M. Feltey. "Here's Looking at Her: An Intersectional Analysis of Women, Power and Feminism in Film." Journal of Gender Studies, vol. 26, no. 6, 2017, pp. 618-631.

Uggadottir, Isold, director. And Breathe Normally. Netflix, 2018.

Wittekind, Courtney T. "A Space 'In-Between': Liminality and Landscape on the Thailand-Burma (Myanmar) Border.” Visual Anthropology Review, vol. 32, no. 2, Fall 2016, pp. 180-191. 